\title{
Discourses of Institutionalization of Zakat Management System in Contemporary Indonesia: Effect of the Revitalization of Islamic Economics
}

\author{
Mari Adachi \\ Kyoto University
}

\begin{abstract}
In Indonesia, zakat management was trying restructured in a top-down form based on the system followed in Malaysia and, in 1999, a related law was enacted. Although many previous studies have been conducted on zakat for its fundamental spiritual aspects and social roles, macroscopic research on its history of both theory and practice aspects is lacking. The transformation in the administrative reform of zakat, which focuses on not only the discourse of Islamic intellectuals but also the tone of the emerging Islamic economy and attitude of the management organization's practitioners and players, is important to understand the growth of Islam in Indonesia. This paper discusses how the zakat practice, which was an individual practice, expanded to include new objectives such as community development or financial inclusion without losing its original spiritual significance. Further, the paper clarifies how an institutionalized approach to zakat management helps in the development of new theoretical intervention areas and contributes to community development and empowerment, without compromising the original poverty alleviation programs.
\end{abstract}

Keywords: Zakat management, Indonesia, Islamic economics

\section{INTRODUCTION}

Zakat is the third important pillar of Islam. It refers to the obligatory payment of a determinate portion of one's lawful property by Muslims for the benefit of the poor and other groups of people enumerated in the Qur'an. The lexicological meaning of zakat is 'to purify'. In addition, it carries the connotations of 'growth' and 'increase'. In Indonesian Muslim communities, zakat is of two types: (1) zakat fitrah (zakāt al-fitr; it is donated at the end of the Ramadan, is calculated as a flat fee for each person, and is similar to a poll tax), and (2) zakat mal (zakāt al-māl; it is paid on the basis of a person's wealth). Often, the general term zakat refers to both the aforementioned types. Theoretically, zakat means providing a fixed proportion of one's wealth to eight specific categories of recipients (asnāf). The required payment on wealth is $2.5 \%$ of a person's total annual income. Since it refers to the purification of accumulated wealth, zakat is both a type of tax on wealth and a pious act ( 'ibādah). It is an obligation for every Muslim who possesses certain assets, such as gold, silver, jewellery, cash, livestock, and agricultural produce, to pay zakat for every one-year period (hawalan hawli) of their ownership. Islamic law regulates that both types of zakat are compulsory (wajib) for Muslims, although these types remain moral obligations in the sense that no legal obligation is imposed by the state.

From an Islamic perspective, some systems genuinely promote economic justice, equality, and social welfare by implementing redistribution mechanisms. In particular, zakat is no longer correlated merely with the aspect of religiosity alone; it is strongly connected to economic targets, as well. Zakat is an obligation (ibādah mahdah) with socio-economic 
objectives (al-ibādah al-māliyyah alijutimaiyyah), such as redistribute income, reduce poverty, and achieve social welfare. Many scholars have pointed out these tripartite effects.

This paper reviews the existing discourses on the top-down approach to zakat management in contemporary Indonesia. In particular, it clarifies how this institutionalized approach contributes to the development of new areas of intervention and, without abandoning the original programs of poverty alleviation, to community development and empowerment in Indonesia.

\section{LITERATURE REVIEW}

According to the classification by Malik (2016: 65-67), the entire literature that has been produced to date on the historical development, juristic requirements, and multi-dimensional applicability of zakat can be classified into two categories. The first category comprises literature that deals with the specific juristic issues pertaining to zakat (fiqh al-zakāt). Such literature includes the contributions of classical Islamic jurists ${ }^{1}$ (fuqaha), as well as those of some contemporary Muslim economists.

According to Qutb (2000), since it corresponds to a mechanism of redistribution, zakat is instrumental in the achievement of economic justice as envisioned in Islam. In addition, it affects the "purification of property itself, because it means paying what is due on the property, after which its possession is legal

\footnotetext{
${ }^{1}$ El-Din (1986) summarizes the viewpoints of the classical schools of thought as follows: the Hannafi School sets a limit of 200 dirhams, whereas the Shafi'i recommends the provision of life support by giving capital goods to eligible individuals. Further, the Maliki School allows the donation of a year's provision. al-Qaraḍāwi supports Maliki's view in the case of zakat disbursement to children and disabled persons and Shafi'i's opinion on disbursement to able-bodied and qualified individuals (Shehu U.R. Aliyu, 2017).
}

Qutb (2000: 162)'. Similarly, al-Qaraḍāwī (2009), one of the most widely recognized contemporary authorities on zakat jurisprudence, concurs that zakat is a right. Reflecting on the wisdom found in several Qur'anic verses dating back to the Meccan period, he notes that the aim of these verses is to make sincere believers realize that their wealth is not for their personal use alone. A portion of their wealth belongs to the needy as a definite right of the latter, rather than a charitable gift given condescendingly by the payer, without requiring humbleness or pride on the part of the receiver or payer, respectively (alQaraḍāwī, 2009: 9). Further, he affirms that the basic objective of zakat is to solve social problems such as poverty, unemployment, those caused by natural catastrophes, indebtedness, and inequitable income distribution. The zakat approach to dealing with these problems is based on the religion's views regarding these social malaises. Often, Prophet Muhammad associated poverty with a lack of faith. It is a type of bondage or slavery for the individuals who fail to fulfil their needs. The system of zakat distribution provides a solution to the social problem of poverty and a relief to the poor regardless of their race, colour, religion, or ethnicity. Further, Hafidhuddin (2002) advocates that Indonesia, which is the most populous Muslim country in the world, should integrate zakat, religious disbursement (infaq or 'infāq), and charity (sedekah or sadaqa) in its poverty alleviation programs. Islam offers these three instruments for promoting the fair redistribution of income.

Sadeq (1994) found that the institution of zakat helps to eradicate poverty. It is noted that poverty encourages begging, which is condemned by Islam. Further, Sadeq suggests that acute inequality does not exist in a properly functioning Islamic economy because various distributional channels guide Muslims towards a reasonably acceptable standard of equality. Therefore, he claims 
that poverty is not a severe problem in a true Islamic economy.

The second category of zakatrelated literature deals with the economics and financial effectiveness of zakat. From the perspective of Islamic economics, Chapra (2001) emphasizes that it is the duty of the state to ensure that all individuals who are unable to take care of their own needs and require assistance enjoy a respectable standard of living (fakir and miskin). He showed that the collection and distribution of zakat is one of the most important factors that accelerate the distribution of income and wealth in Muslim societies. Surah al-Hasyr (59:7) suggests this idea in the Qur'an as follows: 'Wealth does not continue to circulate merely among your rich'. Chapra (2001) stresses the importance of realizing distributive justice in the society (moral economy), although it does not imply equal rewards for everyone. Some Islamic economists argue that zakat is intended to encourage Muslims to constantly utilize their assets productively because this utilization and circulation of income promotes prosperity (Kahf, 2002).

Several studies focus on the history of zakat management in Indonesia from the perspective of policymaking. Salim (2008) discusses the policy design and strategic steps that can completely support the future development of zakat in Indonesia. $\mathrm{He}$ suggests that zakat disbursement should be managed by the government. Lessy (2009) discusses the development of zakat management for improving Islamic social welfare in Indonesia. This study by Lessy discusses several major issues such as the elements of Islamic welfare efforts, advancement of zakat institutions, and misperceptions of Muslims regarding zakat fitrah and zakat mal. Further, Lessy (2009) elaborates the role of the Indonesian government in regulating zakat and highlights the problems caused by such regulations. He presented the success story of Rumah Zakat Indonesia, which is one of the biggest private institutions of zakat collection all over Indonesia and was founded with the aim of improving Islamic social welfare through its philanthropic activities. Latief (2013) adopts a political perspective and highlights that the emergence of a Muslim movement in the public sphere through formal and informal institutions is a method to transform Islam into a social system. He argues that institutionalized zakat is Islamizing Indonesia.

From an anthropologist's point of view, Retsikas (2014) conducted a survey in Indonesia and examined the key discourses on the reconceptualization of zakat from philanthropy to obligation. He explained that the 'traditional' understanding of zakat is worship and analysed the jurisprudential arguments and discourses that facilitated the aforementioned reconceptualization.

In a detailed historical description of the evolution of Islamic philanthropy and its organizational dynamics in Indonesia, Fauzia (2013) unveils the dynamic interrelation between the Muslim civil society and state. She points out that when the state administration was weak, the Muslim civil society emerged powerful and used philanthropy to challenge the state. When the state administration became powerful, the Muslim civil society tended to weaken; however, the latter continued to find ways to use philanthropic practices in the public sphere to promote social change.

\section{Brief History of Zakat Management in Indonesia}

In the early periods of Indonesian history, the Islamic leaders (ulamā or Kiai; Kyai on Java island) in mosques and Islamic educational institutions (madrasah) or boarding schools (pondok pesantren) collected and managed zakat funds. Among Javanese Muslims, zakat funds were chiefly used for building mosques and madrasahs, which are places of religious education. Towards the end of the nineteenth century, 
the Kingdom of Ace Darussalam declined and the zakat tax levy was left to the ulama whereas the land tax continued to be levied by the state. After the decline of the Kingdom of Ace Darussalam, the Dutch colonial government adopted similar policies for levying taxes (Fauzia, 2013: 85). During the Dutch era in Indonesia, religious leaders participated in the collection and distribution of zakat. They used zakat funds to promote the education and welfare of people and to support the armed struggle against Dutch colonization. However, this practice did not last for a long time: once it understood that zakat funds were being used to undermine its authority, the Dutch administration created an effective system to suppress zakat institutions. The political goal of the Dutch was to control zakat, take away a financial resource from Indonesian Muslims, and undermine the Muslims' fight against colonization (Salim, 2008).

After Indonesia proclaimed its independence in 1945, zakat management continued in local communities. There was no coordination among provinces, and there were no mutual programs established to link one province to another for zakat collection and distribution. In the early stages of establishing an independent government in Indonesia, the involvement of the state in managing zakat was unclear. During the Old Order (Orde Lama; in this paper, this term refers to the regime of President Sukarno period, the government did not assign matters related to zakat to the Ministry of Religious Affairs. It was only in 1968 that President Suharto of the New Order officially instructed three highranking military officers to establish an organizational apparatus for nationwide zakat collection. On November 26, 1968, the president gave a speech during the holiday for Isra and Mi'raj on the capability and responsibility of the state regarding the collection of zakat. After the speech, the president presented Presidential Decree No. 07/PRIN/10/1968 on zakat, which required government offices to establish mechanisms for collecting zakat in their legislative districts, and encouraged the incorporation of affairs relating to zakat within the responsibilities of the state (Saidurrahman, 2013: 372). Approximately 2 months after the president gave his speech, Ali Sedikin, who was the governor of Jakarta at the time, established a public zakat agency named Badan Amil Zakat (BAZ) (or The Office for the Management of Zakat), which later changed its name to Badan Amil Zakat Infaq dan Sadaqah (or The Office for the Management of Zakat and Charity) in 1976.

Eventually, in 1968, the important changes in the discourse of Muslim intellectuals regarding zakat management were supplemented by the following joint statement by the pesantren(or Islamic boarding schools in Indonesia): 'the Ulema's urgent task is to formulate the zakat system to innovate the present situation of this society. However, we should not forget about the spiritual value of the religious worship (ibādah)' (Ariff, 1991: 53). Following a notable year of governmental interest and involvement in zakat, several public zakat organizations, such as Badan Amil Zakat Nasional (BAZNAS) (or The National Board of Zakat), were gradually established in many states.

\section{Revitalization of Traditional Islamic Economic Institutions}

During the 1980s, an Islamic revival movement emerged worldwide and zakat management became an important topic of debate among Islamic intellectuals. In addition, since 2000 , the traditional system of Islamic economy has been restored. According to Asutay (2012), The phenomenal growth of the Islamic banks and financial institutions (IBFIs) has been remarkable since it came into existence just over forty years ago. He made reference to the norms and values of IBFIs as formulated by the Islamic moral economy 
(IME), which give meaning to the 'Islamicness of IBF' (Asutay 2012: 94), and he made a new framework of IME in order to share the aspiration of Islamic economics and express the distinguishing nature of IBF. In short, he gave new framework in Islamic economics and distinguished growth of IBF for three stages. The first is from 1963 when the Mith Ghamr saving bank was established in Egypt as the first Islamic bank and Tabung Hajj in Malaysia since 1967 have demonstrated that IBFIs can contribute to the development of society, as the first institutional phase of IBF. The 'commercial' IBF since the mid-1970's constitutes the 'second stage' of the institutionalisation in IB. The third stages are institutions and non-banking-financial institutions, which can include Islamic social banking, Islamic microfinance ${ }^{2}$, economic empowerment oriented awqaf (pious foundations), zakat funds for development, ar-rahn or Islamic pawnbroking institutions, Islamic development banks, social investment institutions, and ethical funds etc (Asutay 2012: 109). He advocated the necessity for the third phase in order to contribute the development of society and manage to touch the lives of ordinary people on the street of the Muslim world and beyond.

Nagaoka (2014) also researched about institutionalization of IBFs. He stated that after the middle of the first decade of the twenty-first century, new trends prioritizing the Sharia Legitimacy Condition emerged in Islamic economics in order to overcome the situation that was

2 For details on Islamic microfinance, see Obaidullah, M., and K. Tariqullah, Islamic Microfinance Development: Challenges and Initiatives. Jeddah: IRTI-IDB, 2008. For more information on zakat-based Islamic microfinance, see Ahmed, H., Role of Zakah and Awqaf in Poverty Alleviation, Jeddah: IRTI-IDB, 2004. And and Ismail, A. G., and B. T. Possumah, "Theoretical Model for Zakat-Based Islamic Microfinance Institutions in Reducing Poverty", International Research Journal of Finance and Economics, no. 103, 2013, pp. 136-150. faced by the Sharia-compliant finance and economy. He defines two such trends: the first trend, which is referred to as 'New Horizon 1.0', pertains to the development of new areas in the practice of Islamic finance, and the second trend, which is called 'New Horizon 2.0', pertains to the revitalization of traditional Islamic economic institutions, such as waqf or zakat, by utilizing Islamic finance (2014: 13-19). He re-evaluated their roles in ensuring the sustainable development of the Muslim community, as well as in tapping new markets for Islamic finance. Both scholars analysed the growth of IBFs into several trends and stressed the importance of traditional Islamic economic Institutions or zakat funds. This kind of trends can also be seen in institutionalization of Islam in Indonesia.

\section{Reconceptualization of Zakat Duties in Indonesia: Zakat and Tax}

What is the difference between zakat and tax? Further, who should have the responsibility of collecting, managing, and distributing zakat? Many scholars have discussed this fundamental question. Before enumerating the earlier discourses of scholars, it is important to confirm the type of approaches adopted by Muslim countries regarding zakat. Nowadays, Muslim countries practice various approaches regarding the zakat system, which can be grouped into three categories. First, some countries have no governmental system for zakat, which is the most common approach. Second, in some countries, although the payment of zakat is voluntary, it comes under some form of governmental monitoring: in such cases, the government facilitates the collection, management, and distribution of zakat to ensure transparency and accountability with varying degrees of oversight and involvement. Bahrain, Bangladesh, Egypt, Iran, Jordan, Kuwait, Lebanon, and the United Arab Emirates adopt this system. 
Third, in some countries, zakat is mandatory: it is treated like a tax and distributed as a means of welfare, and zakat evasion is punishable with fines, imprisonment, or both. Countries that have adopted this system are Libya, Malaysia, Pakistan, Saudi Arabia, Sudan, and Yemen (Alfitri, 2017: 102, quoted in Powell, 20092010: 58-73). In particular, in Saudi Arabia, zakat is regarded as a property tax and, according to Fukuda (2000: 75, quoted in Saudi Arabian Government, Memorial of the Government of Saudi Arabia, 1955, Saudi Arabian Government, 291-327), the term zakat is generally used to denote a type of tax.

In Indonesia, where the population comprises mainly of Muslims, even though Islam in this country is not stipulated as state religion, discussions regarding zakat and tax or the institutionalization of the Islamic finance system are important. When did the concept of zakat start changing in Indonesia, and who was responsible for this change? Some scholars argue that the redefinition of zakat was done by Islamic intellectuals, and it is seen from approximately the mid-1970s that the discourses of two Islamic intellectuals significantly contributed to this redefinition. This chapter relies heavily on the detailed research conducted by Retsikas on the redefinition of zakat in 2016.

Clearly, the change started during the mid-1970s, and it definitely continued from the 1980s onwards, partly as the result of a broader movement for the 'renewal' of Islamic faith (gerakan pembaharuan Islam) and partly in response to the political and economic changes that were brought about by New $\mathrm{Order}^{3}$ policies. During the period 1974-1975, Abdullah (1991) conducted a survey on Indonesian Ulema (Ulamā) and

\footnotetext{
3 'New Order (Orde Baru) Regime' is the term coined by President Suharto, the second Indonesian president, to characterize his regime when he came to power in 1966. Recently, this term has become synonymous with the Suharto years (1966-1998), and this paper refers to this use of the term, as well.
}

the Muslim intellectuals' opinions on zakat management. Most respondents stated that the government is an important factor in zakat management. Whereas a few intellectuals $(7 \%)$ opined that the government should take over zakat management completely, the majority (59\%) supported the collection of zakat through a state-based zakat organization. In addition, approximately half of the respondents $(46 \%)$ stated that a state-based zakat organization should be responsible for the distribution of zakat, as well (Abdullah, 1991: 53).

During the 1980s, many forums and workshops on zakat management were conducted and actively maintained. The main topics were 'Zakat and Tax' and 'Professional Zakat'4, both of which were initiated by one proposal. In 1986, Amien Rais, who was a political scientist and later became a leader of Muhammadiyah (19952000), which is one of Indonesia's largest modernist organizations, delivered a controversial speech. He advocated the reinterpretation of zakat within the contemporary context of Indonesia's persistent problems regarding poverty and sought to redefine its purpose in securing people's welfare. From the perspective of Islam as a religion of justice, Rais (1987, see also Latief, 2012: 85-87) proposed the notion of professional zakat, or zakat on regular income (salary and wages). According to Retsikas (2014), Rais's notion dominated the discursive landscape of zakat in Indonesia since it had several salient features. First, it was an innovation in Islamic jurisprudence, since salary and wages had not previously been considered as wealth sources that can be subject to zakat, according to classically trained scholars. Second, the notion reflected the changes that were occurring in the political

\footnotetext{
4 Professional zakat is a type of zakat that is paid from professionals' fees after certain nisāb. Regarding formal jobs, which have to pay professional zakat, civil servants, consultants, doctors, notaries, accountants, and so on, are determined.
} 
economy of Indonesia at the time, in particular, the broad transformation from an agriculture-based economy to an industrial one where people practiced different professions and received regular income. The change in the payment of zakat as rice to its payment in cash is indicative of the aforementioned broader transformation. Third, the ratio of zakat to wealth proposed by Rais was significantly higher than the ratio that had been applied to other categories of wealth by classically trained scholars. According to Rais, $2.5 \%$ of an individual's wealth was not sufficient for the achievement of public welfare and implementation of social justice (Retsikas, 2014: 345-346).

Amien Rais's proposal was met with dismay by many scholars for being an unlawful innovation (bid'ah) until it was finally accepted in 2003 by the Indonesian Ulama Council (Majelis Ulamā Indonesia, MUI), almost 20 years after it was first proposed', as discussed by Retsikas (Retsikas 2014: 346$)^{5}$. Two years after his controversial speech, in 1988, the Majelis Ulamā Indonesia (MUI) conducted a seminar on zakat and tax and concluded that Indonesian Muslims had to pay both zakat and tax because there are definite differences between them. It was argued that zakat is a religious duty to God, which is stated in the Qur'an or Sunnah, whereas tax is a duty to the nation or state. Moreover, when justified religiously, tax contributes to public welfare (al-maslahat al'ammah). According to Salim (2008: 39), this conclusion implied a double burden for Indonesian Muslims to pay both secular tax and zakat.

Five years after controversial speech of Rais, Masdar Farid Mas'udi,

\footnotetext{
${ }^{5}$ See fatwa no. 3, year 2003, on Zakat Penghasilan (Himpunan, 2003: 87). Eventually, a zakat percentage of $2.5 \%$ was applied to the ownership of gold and silver. Rais' proposal, by contrast, was based on analogizing professional zakat to zakat for the agricultural produce of irrigated fields $(10 \%)$ and zakat for natural resources such as oil and precious metals $(20 \%)$.
}

another Islamic scholar, reignited the issue regarding the social relevance of zakat with the publication of his book The Religion of Justice (1991) ${ }^{6}$. However, in contrast to Rais, Mas'udi had received training in the classical Islamic sciences and, in his youth, had been involved with faith-based nongovernmental organizations. Mas'udi stated that justice is the ultimate goal of the sharia and ijtihad is required for applying this divinely inspired justice to the different contexts and circumstances applicable to Muslims. In this regard, the relationship between zakat and economic justice has paramount importance. Both Rais and Mas'udi highlighted the social dimensions of zakat and emphasized its redistributive purpose.

In addition to the aforementioned discussion of Retsikas, I specify Hafidhuddin as the individual who significantly contributed to the redefinition of zakat. With the intensification of the discussion on reframing duties and increase in the emphasis on the obligatory aspects of zakat, issues concerning zakat and taxation topped the agenda. In this context, the Zakat Management Law No. 38 of 1999 and Tax Law No. 17 of 1999 (which amended Tax Law No. 7 of 1983) assert the similarity between the aims of zakat and tax. Both are obligations binding the Muslim citizens of Indonesia; however, according to Hafidhuddin (2002: 143), zakat is considered an absolute obligation, whereas tax is a relative one. K. H. Didin Hafidhuddin (1951-to the present) was born in Bogor, west Java. He obtained a bachelor's degree from the Department of Syariah, UIN ${ }^{7}$ Syarief Hidayatullah Jakarta, and majored in Arabic from Islamic University of Madinah, Saudi Arabia. He obtained a master's degree from Bogor Agricultural University (IPB) and a $\mathrm{PhD}$

\footnotetext{
${ }^{6} \mathrm{He}$ pointed out the fundamental similarity between zakat and state taxation. The name of the book in Indonesian is Agama Keadilan: Risalah Zakat(pajak) dalam Islam.

${ }^{7}$ Universitas Islam Negiri is the National Islamic University under the Ministry of Religious Affairs.
} 
from UIN Syarief Hidayatullah Jakarta. Regarding his career, he has worked as a lecturer in several universities, such as Pascasarjana IPB, UIN Syarief Hidayatullah Jakarta, and UIKA (Universitas Ibn Khaldun) Bogor. $\mathrm{He}$ worked as the head of BAZNAS for eight years for two periods as the head of BAZNAS. In addition, he worked on the committee of Ulama in DSN (Dewan Syariah Nasional) and $\mathrm{MUI}^{8}$ and headed the committees in several Islamic banks.

With respect to his written works, he has written approximately 20 books on Dakwa, education, economy, and zakat. He translated five books from Arabic to the Indonesian language, including Fiqh Zakat of al-Qaraḍāwī. Hafidhuddin published the Fatwa of Zakat in 2011 as one of the members of the ulama in MUI. This fatwa can be regarded as a fatwa that strengthens theory. In terms of practice, he established Dompet Dhuafa (DD) ${ }^{9}$, which is one of the largest private zakat organizations (Lembaga Amil Zakat, LAZ) in Indonesia, and this organization received the Ramon Magsaysay Award in 2016. In summary, he has contributed to zakat development in Indonesia from both theoretical and practical perspective. In particular, he was someone who promoted the administration of zakat.

The discourse of Islamic intellectuals contributed to the theoretical

\footnotetext{
8 Majelis Ulama Indonesia is Indonesia's top Muslim clerical body. The council comprises many Indonesian Muslim groups. It was founded by the Indonesian New Order regime under the Suharto administration in 1975 to produce fatwa $\bar{s}$ and advise the Muslim community on contemporary issues.

$9 \mathrm{DD}$ is the largest Islamic philanthropic organization in Indonesia today, in terms of donations received. In 2015, DD collected total donations equivalent to USD 20.2 million With offices in 12 Indonesian provinces and five foreign countries, DD's 200 employees and 10,000 volunteers have reached 13 million beneficiaries as of 2015 , of whom at least $20 \%$ have moved out of poverty (http://rmaward.asia/news/citation2016-ramon-magsaysay-awardee-dompetdhuafa/).
}

advancement of the objectives of Islamic law (maqāṣid al-sharī'a). The legal views advocated by al-Qaradāwī (2009), Rais (1987), Mas'udi (1991), and Hafidhuddin (2002) initiated in-depth discussions on a paradigm shift in zakat practices, which considered issues regarding top-down administration and its legal basis.

\section{Legislation of Zakat Management}

With the end of the New Order era, the number of Islamic charitable organizations increased and grew rapidly. Zakat Management Law No. 38/1999 was enacted by President Habibie ${ }^{10}$, who succeeded President Suharto in 1998. The law promised to regulate and enhance the accountability of zakat-collecting agencies in Indonesia. It covered both the semigovernmental collecting agencies (BAZ) and non-governmental collecting agencies (LAZ). BAZ and LAZ have the same functions: collect, distribute, and utilize zakat proceeds efficiently. Submitting balance sheet audits and annual reports to the government is required, which encourages public disclosure. This piece of legislation regulates zakat management institutions, in general; however, it does not make zakat payments obligatory. The most remarkable thing about Zakat Management Law No. 38 is Article 14, which explicitly states that those who pay zakat (muzakky) to BAZNAS are entitled to receive a $2.5 \%$ deduction for income tax. Article 9 in Tax Law No. 17 of 2000 contains the same clause. This exemplifies the legislators' consideration of the issues of zakat and tax, which is discussed in Section 4.

On January 17, 2001, BAZNAS, a semi-governmental zakat management organization, was established. Zakat Management Act No. 23 of 2011 amended Zakat Management Law No. 38 of 1999 and delegated the integration of zakat

\footnotetext{
${ }^{10} \mathrm{He}$ signed to make a draft of zakat management law in June 24, 1999.
} 
management completely to BAZNAS. According to Fauzia's (2013) survey, around $34 \%$ of all zakat management organizations were new institutions established in the first five years of the Reformasi period.

The 1980s saw Indonesia at the height of its prosperity as the country opened up its economy to foreign investment and furthered export-oriented industrialization. However, the fruits of economic development were unevenly distributed and did not reach large parts of the country, particularly, the rural areas. A new generation of Muslim intellectuals found this situation difficult and worked hard to rectify it through various interventions. Despite the economic growth, the gap between the rich and the poor did not seem to be shrinking. The dissatisfaction among Muslim intellectuals and zakat management organizations, concerned about the implementation of the concepts of Islamic economics, justice for inequality, and moral economy, was increasing.

\section{The Rise of Islamic Economics: Orientation to Justice and Moral Economy}

Although Indonesia gradually achieved economic growth, the generated wealth did not seem to be distributed towards the poor. This situation made Islamic organizations, including the largest Muslim organization in Indonesia Nahdlatul Ulama, seek justice in a different arena and guise. The demands were articulated anew in Islamic economics with the claim that an Islamic economic system, based as much on the prohibition of usury $(r i b \bar{a})$ as on the promotion of zakat, would have possibility to achieve better economic fairness than either the capitalist or socialist systems.

Chapra (1992) admonished all economic activities that contribute to the wastage of economic resources and human welfare; recommended individual restrictions, both material and spiritual; and encouraged the enhancement of overall social welfare. Further, he opined that the objectives of Islamic law (maqāșid alsharī' $a$ ) would be realized by adopting a political and economic system that induces such practices, in addition to individual practices that are consistent with Islamic economics (Chapra, 1992: 213-223).

Mawdudi (1975 [1947]), one of the important modernist Islamic economic thinkers, accepted the private ownership system of modern capitalism and the differences between rich and poor individuals. However, he pointed out that the absence of a redistribution system to rectify these differences constituted a problem. In addition, he discussed the necessity of accepting private ownership unless it is contrary to the philosophy of fairness in Islam and using zakat to improve income redistribution (Mawdudi, 1975 [1947]: 16-17, 36-39).

In Indonesia, a model that incorporates the Islamic sense of justice was sought primarily to revitalize societal norms and practices through promoting Islamic values, not to reconstitute the state. At the same time, the creation of Islamic institutions, such as sharia-compliant banks and cooperatives, along with the establishment of zakat management organizations have been actively supported by modern Islamic economic thinkers.

Recently, in 2015, the institutional structure of BAZNAS underwent a drastic renovation. Both the institution's current chairman Bambang Sudibyo and vicechairman Zainulbahar Noor have an educational background in economics (The National Board of Zakat, 2017), whereas almost all the former presidents of BAZNAS were Islamic jurists. This choice of top managers reflects the strategy of BAZNAS to maintain its image of being a professional, transparent, and trustable organization that is responsible for managing the zakat funds. The vicechairman is Zainulbahal, who is educated in economics and Islamic finance, as well. He has worked as the director of several 
banks. Moreover, one member of the committee is Masdul F. Mas'udi, one of the important Islamic scholar, who is mentioned in the former section as one of the Muslim scholars who discussed about zakat institutionalization in Indonesia and put down some prescriptions regarding zakat and secular tax. In 2016, the Centre for Strategic Studies (Pusat Kajian Strategis, PUSKAS) was established at BAZNAS to support the building of a professional zakat institution through research-based programs ${ }^{11}$. The centre organized a national zakat seminar on December 8, 2016, at the University of Indonesia. In his keynote speech, Bambang Sudibyo, the chairman of BAZNAS, and Didin Hafidhuddin, the former president of BAZNAS, addressed the importance of the duty of zakat. Many shariah scholars, researchers, and staff of the institution engaged in conversations at the seminar ${ }^{12}$. Many presentations at the seminar discussed the possibilities of zakat as a financial resource in promoting social welfare.

The zakat management debate between Muslim intellectuals in Indonesia attained maturity before the twenty-first century, as its attention shifted to the economic utility and development of zakat. This shift in argumentation is in line with the theory and concept of Nagaoka's (2014) New Horizon 2.0. Jurisprudential arguments and discourses of Muslim intellectuals reconceptualize zakat from a simple ritual of worship to a fundamental instrument for achieving socio-economic justice.

11 Based on the details in a website (http://puskasbaznas.com).

12 The content of this seminar, including presentations and video recordings, is available on the PUSKAS BAZNAS website (Center of Strategic Studies, The National Board of Zakat, 2017).

\section{CONCLUSION}

This paper summarizes the issues raised by two discourses on the top-down approach to zakat management in contemporary Indonesia. The first is the discourse of Muslim intellectuals on a theoretical reconceptualization of zakat, incorporating the objectives of Islamic law (maqāsid al$\operatorname{sharī}^{-} a$ ). Legal views advocated by alQaradawi (2000), Rais (1986), Mas'udi (1991), and Hafidhuddin (2002) have initiated a discussion on a paradigm shift concerning zakat practices in Indonesia. The in-depth discussions provided a legal basis for further developments and inspired top-down administrative efforts in the country's zakat system. The second discourse advocated by two Islamic economist Asutay (2012) and Nagaoka (2014) refers to the growing interest of Islamic Moral economy regarding to social justice and community development, which has spurred discussions on zakat. Simultaneously, the 'reconceptualization of zakat from philanthropy to obligation' led by Muslim intellectuals and an institutionalized approach to zakat contributed to the development of new areas of intervention.

This study underlines several consequences of the two main discourses of Muslim intellectuals and Islamic economists to find new external viewpoints regarding the role of zakat in achieving sustainable development in Indonesia. Both discourses highlight the impact of zakat as an effective tool in the promotion of social welfare by means of philanthropy, empowerment, and community development in the Muslim society. In other words, an institutionalized approach to zakat helps to find new areas of intervention and, without abandoning the original programs of poverty alleviation, it has found a way to support community development and empowerment in presentday Indonesia. Finally, the two discourses on revitalization are not simply attempts to resuscitate the antique Islamic 
jurisprudence in contemporary Indonesia; they additionally contribute to the recent developments and changes in how zakat is used as an instrument to eradicate poverty.

※ This work was supported by JSPS KAKENHI (Grant-in-Aid for JSPS Research Fellow) Grant Number 16J10818.

\section{REFERENCES}

Alfitri. (2017). "My Zakat is My Money, Islamic Commercial Banks Responses to State Intervention in Zakat Administration in Indonesia" World Zakat Forum (WZF) International Conference Proceedings, $\quad$ pp. 99-112. [https://www.researchgate.net/publi cation/323252040].

Ariff, M., ed. (1991). Islam and the Economic Development of Southeast Asia: The Islamic Voluntary Sector in Southeast Asia. Singapore: Institution of Southeast Asian Studies.

Asutay, M. (2012). "Conceptualising and Locating the Social Failure of Islamic Finance: Aspirations of Islamic Moral Economy vs the Realities of Islamic Finance", Asian and African Area Studies, vol. 11, no. 2, pp. 93-113. [https://www.asafas.kyotou.ac.jp/dl/publications/no_1102/AA 112_02_Asutay.pdf].

Salim, A. (2008). Challenging the Secular State: The Islamization of Law in Modern Indonesia. Honolulu: University of Hawaii Press.

Badan Amil Zakat Nasional. (2011). Himpunan Fatwa Zakat MUI: Kompilasi fatwa MUI tentang Masalah Zakat (Association of Fatwa Zakat MUI: Compilation of MUI fatwa on the issue of Zakat). Jakarta: BAZNAS.
Chapra, M. U. (1992). Islam and the Economic Challenge. Herndon: International Institute of Islamic Thought; Nairobi: KARO, The Islamic Foundation.

Chapra, M. U. 2001(1996). What is Islamic Economics? Jeddah: IRTI-IDB.

El-Din, A.K. (1986). 'Ten years of Islamic banking', Journal of Islamic Banking and Finance, vol. 3, no. 3:4966.

Fauzia, A. (2013). Faith and the State: A History of Islamic Philanthropy in Indonesia. Leiden: Brill.

Fukuda, S. (2000). "Gendaisekai no Doukou to Islam Saudi Arabia ni okeru zakat no choshu: Islam no zeisei to kokka zaisei (Trend of the Modern World and Islam Collection of Zakat in Saudi Arabia-Islamic Taxation and National Finance)", Islam Sekai, vol. 55 no. 1, pp. 7393.

Hafidhuddin, D. (2002). Zakat Dalam Perekonomian Modern (Zakat in the Modern Economy). Jakarta: Gema Insani.

Latief, H. (2012). Islamic Charities and Social Activism: Welfare, Dakwah and Politics in Indonesia. Utrecht: Utrecht University Press.

Latief, H. (2013). "The Politics of Benevolence: Political Patronage of Party-Based Charitable Organizations in Contemporary Indonesian Islam", Al-Jami'ah: Journal of Islamic Studies, vol. 51, no. 2, pp. 337-363.

Kahf, M., ed. (2002). Economics of Zakat. Jeddah: IRTI-IDB.

Kuran, T. (1986). "The Economic System in Contemporary Islamic Thought: Interpretation and Assessment", International Journal of Middle East Studies, vol. 18, no. 2, pp. 135164.

Malik, B. A. (2016). "Philanthropy in Practice: Role of Zakah in the Realization of Justice and Economic 
Growth", International Journal of Zakah, vol. 1, no. 1, pp. 64-77.

Masu'udi, M. F. (1991). Agama keadilan: Risalah zakat (pajak) dalam Islam (The religion of justice: a treatise about zakat (tax) in Islam). Jakarta: P3M.

Mawdudi (Mawdūdī), A. A. 1975(1947). The Economic Problem of Man and Its Islamic Solution. Lahore: Islamic Publications (Originally published in Urdu).

Nagaoka, S. (2014). "Resuscitation of the Antique Economic System or Novel Sustainable System? Revitalization of the Traditional Islamic Economic Institutions (Waqf and Zakat) in the Postmodern Era", Kyoto Bulletin of Islamic Area Studies, vol. 7, no. 1, pp.

[https://repository.kulib.kyotou.ac.jp/dspace/bitstream/2433/1858 39/1/I.A.S 007 003.pdf].

President Suharto(Soeharto). (1985). Amanat kenegaraan: kumpulan pidato kenegaraan di depan Sidang Dewan Perwakilan Rakyat (Statement of the State: a collection of state speeches in front of the House of Representatives Assembly). Jakarta: Inti Idayu Press.

al-Qaraḍāwī, Y. (2009). Fiqh al zakāt (The Rules, Regulations and Philosophy of zakat in Islamic Jurisprudence). Beirut: Al-Risālah al'alamityah LTD.

Qutb, S. 2000 (1949). Social Justice in Islam. Oneonta, N.Y.: Islamic Publications International.

Rais, Amien Muhammad. (1987). Cakrawala Islam antara Cita dan Fakta (The Firmament of Islam between Ideals and Reality). Bandung: Mizan.

Retsikas, K. (2014). "Reconceptualising Zakat in Indonesia: Worship, Philanthropy and Rights", Indonesia and the Malay World, vol. 42, no. 124 , pp. 337-357 [https://www.tandfonline.com/doi/f ull/10.1080/13639811.2014.951519 ].

Sadeq, Abu al Hasan (1994). A Survey of the Institution of Zakah: Issues, Theories and Administration. Jeddah: IRTI-IDB.

Saidurrahman. (2013). "The Politics of Zakat Management in Indonesia: The Tension Between BAZ and LAZ", Journal of Indonesian Islam, vol. 7, no. 2, pp. 366-382 [https://media.neliti.com/media/publ ications/95481-EN-the-politics-ofzakat-management-in-indo.pdf].

Shehu U.R. Aliyu. (2017). "A Treatise on Socioeconomic Roles of Zakah", MPRA Paper No. 81155 [https://mpra.ub.unimuenchen.de/81155/].

Suharto (Soeharto). (1981). "Zakat Adalah Model Ummat Islam untuk Pembangunan dan Memerangi Kemelaratan dengan Cara-cara yang lebih Prinsipil, Sambutan Presiden pada Peringatan Isra' Mi'raj tanggal 26 Oktober 1968 di Istana Merdeka (Zakat is The Model Of The Muslim Community for The Development and Eradicating Poverty with More Principle Methods, The President's Speech at Isra 'Mi'raj Memorial on 26 October 1968 at Istana Merdeka)", Djohan Effendi et al. (eds.) in Agama dalam Pembangunan Nasional Himpunan Sambutan Presiden Soeharto (Religion in the National Development Association of President Suharto's Message). Jakarta: Pustaka Biru.

Abdullah, T. (1991). "Zakat Collection and Distribution in Indonesia", in Ariff, M. (ed.), The Islamic Voluntary Sector in Southeast Asia. Singapore: Institution of Southeast Asian Studies.

Lessy, Z. (2009). "Zakat (Alms-Giving) Management in Indonesia: Whose Job Should It Be?", La_Riba Jurnal 
Ekonomi Islam, vol. 3, no. 1, pp. 106-119.

Mari Adachi

Graduate School of Asian and African Area

Studies

Kyoto University

mariadachi@asafas.kyoto-u.ac.jp 